\title{
Panorama de lo epistolar en la poesía española peninsular contemporánea escrita por mujeres
}

\section{A Survey of the Epistolary Dimension in Peninsular Contemporary Women Poets}

\author{
Elena Vega-Sampayo \\ University of Texas Rio Grande Valley \\ elena.vega@utrgv.edu \\ ORCID iD: https://orcid.org/0000-0002-9621-6935
}

\section{RESUMEN}

El presente artículo se propone interpretar la elección por parte de algunas poetas de lo que a priori parecieran meras huellas, vestigios del género epistolar. Con ese objetivo se analizarán obras de distintos momentos y generaciones de la poesía española contemporánea del siglo XX y hasta nuestros días que tienen como común denominador su acercamiento a lo epistolar. Buscamos dar testimonio de una realidad poética singular, amén de examinar sus conexiones con la tradición. Utilizando como marco referencial el estudio del apóstrofe propuesto por J. Culler, se llevará a cabo un recorrido transversal de lo epistolar, así como un análisis de las técnicas y figuras retóricas relacionadas, en la poesía peninsular contemporánea escrita por mujeres que incluirá, entre otras, a Rosa Chacel, Ernestina de Champourcín, Gloria Fuertes, María Victoria Atencia, Julia Uceda y Eloísa Otero.

Palabras Clave: poesía peninsular contemporánea; género epistolar; apóstrofe.

\begin{abstract}
This paper seeks to interpret the choice by some Peninsular women poets of what would initially seem to be mere traces, sheer remnants of the epistolary genre. To this end, a score of $20^{\text {th }}$ and early $21^{\text {st }}$ century works of Contemporary Peninsular Spanish women poets will be analyzed, bearing witness to a singular poetic reality, inasmuch they share an approach to the epistolary genre, and scrutinizing their connections with the literary tradition. By resorting to J. Culler's analysis of the apostrophe as a framework of reference, as well as to a specific analysis of the literary techniques and rhetorical figures involved, a cross-sectional study of the epistolary dimension of Peninsular, Contemporary women's poetry is conducted. This includes, among others, works by Rosa Chacel, Ernestina de Champourcín, Gloria Fuertes, María Victoria Atencia, Julia Uceda, y Eloísa Otero.
\end{abstract}

Key words: Contemporary Peninsular Poetry; Epistolary Genre; Apostrophe. 


\section{INTRODUCCIÓN}

El presente artículo explora la pervivencia (y sus manifestaciones) del género epistolar ${ }^{1}$ en la poesía peninsular contemporánea escrita por mujeres. Si bien parece obvio que no puede decirse que dicha pervivencia goce, ni remotamente, de la exuberancia que tuvo, por ejemplo, la epístola horaciana en la España del Siglo de $\mathrm{Oro}^{2}$, se analizará un corpus de poemas que el ojo crítico percibe como vestigios, categoriza bajo la etiqueta de «lo epistolar» y pudiera quizá haber conformado tendencia.

Si bien las cartas fueron tradicionalmente territorio literario femenino, puesto que evidenciaban el carácter intimista y emotivo atribuido a la mujer ${ }^{3}$, en la

${ }^{1}$ Cabe destacar tres momentos en la producción de obras pertenecientes al género epistolar. Aludiremos primero al corpus epistolar horaciano. En el s. I a. C. Horacio compone veinte epístolas de menor extensión que sus sátiras, cuyos temas principales son «la filosofía, la crítica moral, el interés autobiográfico, el cultivo de la amistad y la crítica literaria» (Silvestre 1996, 36). A estas deben sumarse tres epístolas de mayor extensión sobre temas literarios: Epistola a Augusto, Epístola a Floro y Epístola a los Pisones o también conocida como Arte poética. Horacio escribe todas sus epístolas, al igual que sus sátiras, en hexámetros latinos; de ahí que pueda considerarse este último como «un vínculo formal inapelable entre [...] Sátiras, Epístolas y Arte poética» (ibíd., 1996, 30). En un segundo momento y a partir de la recuperación completa de las obras horacianas en el Renacimiento aparece «la epístola en verso», nuevo género en el que confluye la intimidad del poeta con la afirmación de los valores éticos del Humanismo «al modo horaciano». Por último, siendo Petrarca su precursor, hacia 1500 el género estaba consolidado tanto en latín como en lengua vernácula.

${ }^{2}$ La epístola horaciana gozó de un enorme prestigio en la España de los siglos XVI y XVII. El género aparecerá en España con Garcilaso de la Vega y su «Epístola a Boscán» (1534), al que seguirán el intercambio epistolar de Juan Boscán y Diego Hurtado de Mendoza. Véase «Sátira y poética en Garcilaso» (Guillén 1988, 15-49). Luego vendrán la «Epístola a Arias Montano» de Francisco de Aldana (1577), las epístolas de Gutierre de Cetina, las de Lupercio y Bartolomé Leonardo de Argensola y, la «Epístola moral a Fabio» de Andrés Fernández de Andrada, esta última considerada una de las cimas del género: véase «Estudio preliminar» de Juan F. Alcina y Francisco Rico y «Prólogo» de Dámaso Alonso a su ya clásica edición (Fernández de Andrada 1993, IX-XXXII y 1-69).

3 «Desde el siglo XVII parece un lugar común asegurar que la carta es un género propiamente femenino» (Navarro 2011, 220). Gabriel Sánchez Espinosa subrayará, a partir de la valoración de la obra de Madame Sévigné, la conciencia de la superioridad de la mujer en el género epistolar por parte de estudiosos como el exiliado jesuita Juan Andrés, quien en el tomo V de su Origen, progresos y estado actual de toda literatura (1789) alude a Madame de Sevigné como «la soberana maestra y la verdadera Reyna del estilo epistolar» y no conformándose con un nombre propio considera que «el genio de escribir cartas se encuentra particularmente en las mujeres francesas, muchas de las cuales tienen raros talentos para este género de escritos» (Sánchez Espinosa 2001, 121). Antonio Jiménez Millán cita la definición de «género femenino» por excelencia que Béatrice Didier da al género epistolar en su estudio L'Ecriture-femme de 1981, llevando a cabo un breve repaso histórico de ilustres escritoras de cartas desde la baja Edad Media al Renacimiento (Jiménez Millán 
actualidad ya no es necesario utilizar tal género como parapeto ni como subterfugio. Por el contrario, el recurrir a él pudiera producir incluso cierto reparo o prejuicio debido a antiguos matices. Sin embargo, lo epistolar sigue utilizándose no solo en el ámbito de la narrativa contemporánea ${ }^{4}$ sino que pueden rastrearse poemas que presentan marcados rasgos epistolares. Así, la compilación de una serie de poemas que evidencian su carácter epistolar, en muchos casos desde su mismo título, no carece de relevancia, como tampoco carece de ella el detenerse en alguno de los rasgos más significativos que tal elección implica por parte de la poeta. Entre estos, quizá el rasgo más relevante sea la apelación a un tú. Al respecto afirma atinadamente López Bueno:

Sobre ese tú descansa la convención más genuina (y tal vez la única imprescindible) del género epistolar, configurado como un diálogo fingido y fundamentado en la relación de amistad que une a emisor y receptor. Tales dos supuestos condicionan, a su vez, que la epístola, como género poético, se mueva irremediablemente en el territorio de la contingencia y en el ámbito de lo privado (López Bueno 2000, 12).

El formato epistolar presupone, pues, la apelación a un destinatario, y la figura retórica por excelencia en la apelación al destinatario es el apóstrofe ${ }^{5}$. El

2009, 14). Esta adscripción tradicional de la literatura femenina a lo epistolar no es óbice para la existencia de poemas-carta escritos por hombres en la poesía española contemporánea. Destacan, entre otros, poemas como «A José María Palacios» de Antonio Machado o «Carta a Georgina Hubner» de Juan Ramón Jiménez, además de numerosos ejemplos de los poetas de la generación del 27 y del medio siglo.

${ }^{4}$ Sobre la importancia de la técnica epistolar como característica en la narrativa de las escritoras españolas contemporáneas véase, por ejemplo, el artículo de Ángeles Encinar (2000) y de Fuentes Gutiérrez (2000). Carme Riera $(1982,1989)$ ha escrito sobre la literatura femenina y su conexión con lo epistolar, así como sobre la importancia del interlocutor. Para el estudio de este último aspecto es imprescindible el ya clásico de Carmen Martín Gaite (1973). Ambas autoras han escrito algunas de las mejores novelas epistolares contemporáneas en lengua española.

${ }^{5}$ En El lenguaje literario. Vocabulario crítico se clasifica el apóstrofe como figura retórica dentro de las intensificaciones (figuras retóricas que, a diferencia de las licencias, no transgreden la norma lingüística [Garrido Gallardo 2009, 165]) y se define como «individualización entre los posibles interlocutores del coloquio» (ibíd., 2009, 169). Resulta interesante señalar la consideración del apóstrofe según las reglas retóricas de las poéticas medievales (disposición, amplificación, abreviación) entre los procedimientos de la amplificación, siendo definido como «interpelación con matices que muestran la emoción» (ibíd., 2009, 39). Para Azaustre el apostrofe o apelación a un destinatario textual constituye una nueva forma de evidentia: «Dirigir la palabra a un interlocutor presente en el texto hace más vivo y real aquello que se expresa, como si en verdad se dijese ante el lector» (Azaustre y Casas 1997, 126). Además, lo clasifica dentro del subconjunto de las figuras patéticas (junto con la exclamación, interrogación retórica, optación, imprecación y deprecación), procedimientos o técnicas que tienen por objeto incidir afectivamente en el destinatario [el énfasis es nuestro]. Para Azaustre (Azaustre y Casas 1997, 130) «el intenso efecto de la 
artificio de forzar un interlocutor epistolar-poemático no puede, por lo tanto, sustraerse de un análisis que considere, aunque sea de manera tangencial y como marco de referencia, la figura del apóstrofe. Con esa intención nos acercaremos en el siguiente apartado al valioso estudio de Jonathan Culler, aplicando con liberalidad sus intuiciones sobre el apóstrofe al conjunto de poemas analizados en el presente artículo.

Se dan en la poesía española contemporánea escrita por mujeres composiciones estructuradas sobre anáforas que explicitan la necesidad de devolución, al igual que los poemas que se dirigen desde el mismo título a un receptor o destinatario ${ }^{6}$. Por un lado, estos señalamientos pueden verse como manifestaciones de un rasgo propio, mas no privativo, de un género, el epistolar. Por otro lado, y tal como ya hemos indicado, el género epistolar se inscribe tradicionalmente, junto con el del diario y la autobiografía, en la literatura escrita por mujeres ${ }^{7}$. Señalar entonces la presencia recurrente en la poesía escrita por mujeres de ese tú interlocutor o del apóstrofe como anteriormente citábamos pudiera parecer trivial, más aún si aparece precisamente en composiciones de manifiesto carácter epistolar. Y, sin embargo, la elección de este y otros rasgos inherentes a lo epistolar que iremos viendo en el análisis posterior -o la opción por el molde epistolar ${ }^{8}$, en un momento en el que tal género se reinventa en un mundo regido por la tecnología- merece una aproximación crítica que arroje nueva luz, siempre desde el comentario mismo de los textos ${ }^{9}$.

apóstrofe se ocasiona al variar el normal discurrir del texto (narración, digresión, etc.) mediante la inclusión de un elemento apelativo».

${ }^{6}$ Véase «Dime, dime amor» de Julia Otxoa (1985) como ejemplo de lo primero y «A un joven con abanico» de Ana Rossetti (1980) como ejemplo de lo segundo.

7 «Es decir, si la escritura en general quedaba fuera del ámbito estrictamente femenino dado su carácter público, el pensamiento liberal patriarcal, sin embargo, reconocía a las mujeres su aptitud para el cultivo de la escritura privada (cartas, diarios y autobiografías), los llamados "géneros de realidad" que en este contexto ideológico encajaban perfectamente con la definición de la subjetividad femenina» (Fuentes Gutiérrez 2000, 339).

${ }^{8}$ Claudio Guillén $(1985,165)$ se refiere al concepto de «modalidad» como una taxonomía transversal a la de género propiamente dicha. Dichas modalidades, «tan antiguas y perdurables muchas veces como los géneros, [su] carácter es adjetivo, parcial y no a propósito para abarcar la estructura total de una obra. Son aspectos de ésta, cualidades, vertientes principales, vetas que la recorren transversalmente».

9 Ángel Luis Luján Atienza $(2005,13)$ propone un «enfoque puramente lingüístico» en su Pragmática del discurso lírico, en el que, desde una teoría basada en la experiencia de lectura y en último término textual, considera el texto no como producto cerrado sino como un medio flexible, un «lugar en que quedan plasmados e inscritos los procesos de negociación que, sobre el sentido de su comunicación, llevan a cabo sus interlocutores» (ibíd., 14). Para nuestro análisis resulta especialmente interesante su clasificación de las figuras del receptor lírico en el capítulo V (ibíd., 209-253) en cuatro categorías: la no aparición de segunda persona, el tú como lector, la segunda persona distinta del lector (que incluye ape- 
Nos proponemos, entonces, un recorrido que abarque obras y poetas de distintos momentos y generaciones de la poesía española contemporánea del siglo XX y hasta nuestros días, teniendo como común denominador su acercamiento a lo epistolar y deteniéndonos en el análisis pormenorizado de algunos poemas paradigmáticos de lo que quisiéramos subrayar: al fin y al cabo, vestigios o variaciones de lo epistolar. En este sentido, podremos constatar la paradójica relevancia de la flexibilidad formal y la variedad en el tratamiento de temas que subraya Sánchez Robayna como características del género. El autor insiste en la «flexibilidad» del género epistolar, «hasta el punto de atentar contra sus propios elementos constitutivos sin que su espíritu quede alterado en esencia» (Sánchez Robayna 2000, 140), resaltando que «la esencia del género es la varietas, esto es, la pluralidad de motivos o, si se prefiere, la libertad en que queda el poeta para el tratamiento de sus temas» (ibíd., 141).

El presente estudio nace, pues, con la pretensión de mostrar un panorama lo suficientemente amplio de la poesía epistolar española escrita por mujeres en la península. Tal esfuerzo ni puede ni pretende constituir un catálogo completo, cerrado y definitivo. Ahora bien, lejos de la certeza de poder citar todos los títulos y aludir a todos los nombres, sí buscamos dar testimonio de una realidad poética singular y quizás no lo suficientemente estudiada ${ }^{10}$, amén de analizar sus conexiones con la tradición. Así, después de una breve incursión en el análisis del apóstrofe según Culler, empezaremos con dos autoras de la generación del 27, Ernestina de Champourcín y Rosa Chacel. A continuación, realizaremos una breve singladura por las obras de carácter epistolar de la poesía de posguerra (en concreto la de Ángela Figuera Aymerich, María Victoria Atencia, Gloria Fuertes y Julia Uceda), realizando un análisis algo más pormenorizado de algunas de las composiciones que designamos como paradigmáticas de la dimensión epistolar. Por fin, dedicaremos los dos últimos apartados a autoras y poemas del último tercio del siglo XX (en especial obras de Teresa Ortiz y Eloísa Otero) y principios del siglo XXI, en lo que consideramos un recorrido transversal de lo epistolar en la poesía peninsular contemporánea escrita por mujeres.

laciones a entidades capaces y no capaces de comunicarse, además de la poesía como interlocutora) e interlocutores especiales.

${ }^{10}$ El monográfico que la revista Litoral dedicó a la correspondencia epistolar «Cartas \& Caligrafías» incluía una última sección titulada «Poemas a la carta» (VV. AA. 2009). Se trata de una antología de «los poemas más representativos sobre la hermosa e impagable costumbre de comunicarse por medio de una carta» en la que, de veintiséis poetas, solo seis son mujeres (Gloria Fuertes, María Victoria Atencia, Clara Janés, Cristina Peri Rossi, Ángeles Mora y Aurora Luque). 
A MODO DE MARCO REFERENCIAL

Culler ofreció a principios de los ochenta una clave interpretativa de la figura del apóstrofe que diversos críticos habían soslayado con anterioridad amparándose bien en su supuesta naturaleza de mera convención de género, bien en el hecho de responder a una tradición lírica desprovista de complejidades de interacción comunicativa. Se trataba de una reafirmación de la «hostilidad inherente» que Culler $(1981,136)^{11}$ afirma producirse en la crítica contra la presencia de la voz en el mero acto de la escritura. Lejos de toda intención animista o de personificación de los objetos, para Culler el apóstrofe opera en cuatro niveles de profundidad, que se inician en el plano de la definición dialógica del yo, por oposición al objeto referido como interlocutor, con un valor no tanto emotivo como situacional. Este le permite al poeta «dar la espalda a su audiencia» (Culler 1981, 137), generando así una «intensa implicación con la situación descrita» (ibíd., 138). Así, y en primer lugar, el apóstrofe en particular (y lo epistolar por extensión) es una suerte de generador de marco comunicativo que conlleva una alta implicación situacional: fuerza el planteamiento ostensivo de un «quiero comunicar». La dimensión vocativa (también necesariamente definitoria de lo epistolar) establece en el apóstrofe un segundo nivel de actuación como «relación entre sujetos» (ibíd., 1981, 141).

En un tercer nivel el apóstrofe apela a la identidad de un yo-en-tanto-querelación. Es este tercer nivel de lectura el de mayor operatividad en el corpus de poemas-cartas que hemos seleccionado y por ello le dedicaremos mayor espacio. Para Culler, el apóstrofe no tiene referente semántico y se constituye en la poesía moderna como mecanismo crucial para superar la alienación entre sujeto y objeto. El apóstrofe busca, pues, la reconciliación entre ambos, sujeto y objeto, como un acto voluntario: hablarle a las cosas, o, en la epístola, hablarle al que no está ahí para poder escuchar. Debe subrayarse aquí la indeterminación del tú que resulta consustancial a la figura del apóstrofe y que, en cierta manera, pareciera encajar con la adopción del molde epistolar a efectos líricos: «la substanciación pura de la intención poética, el alegato del sujeto según el cual, en sus versos, no es sin más un poeta empírico o material, el redactor de un verso [en nuestro caso, de un poema-carta], sino la substanciación de una tradición poética» (Culler 1981, 143). Así, esa suerte de residuo sustancial del espíritu de la poesía que reposa en el apóstrofe contribuye a una visión en nuestro estudio de lo epistolar en la lírica femenina como «vestigio», como «viejo remanente» de una tradición poética. Estamos adelantando las conclusiones.

Resulta relevante la frecuencia con la que poemas que contienen apóstrofes que actúan en este tercer nivel de lectura finalizan con lo que Culler (1981,

\footnotetext{
${ }^{11}$ Nos referimos al capítulo «Apostrophe» incluido en su libro The Pursuit of signs. Semiotics, Literature, Deconstruction (Culler 1981, 135-154). Todas las citas del estudio original de Culler, en inglés, según nuestra propia traducción al español.
} 
143) identifica como «un acto de retracción y con cuestionamientos». Vacilaciones y dudas se reflejan en varios de los poemas que analizaremos en los próximos apartados, siendo ejemplar en este sentido el metapoema «Carta» con el que Julia Uceda inicia Zona desconocida.

Culler $(1981,144)$ señalará que, en algunos poemas, la duda afecta incluso al mismo apostrofe en tanto que mecanismo o procedimiento, cuestionándose su eficacia paródicamente, lo que le lleva a caracterizar entonces al apóstrofe como «gesto» concurrente de lo ridículo y lo sublime que no puede sustraerse a cierta autoconsciencia de dicha dualidad, a la par excéntrica y excelsa. Este último señalamiento resulta de enorme utilidad para entender los poemas-cartas de Gloria Fuertes en su conjunto.

En un cuarto y último nivel el apóstrofe opera y puede ser interpretado como acto radical de interiorización («intimista» sería quizás un más apropiado calificativo en el ámbito de lo epistolar) que deriva bien en lo expansivo, para «poblar el universo con fragmentos del yo», bien en lo solipsista, para «interiorizar los objetos que pudieran haber sido concebidos como exteriores», adueñándose del tú y estableciendo el concepto de un yo prefigurado solo-en-tantoque-tú (Culler 1981, 146). Así, siguiendo a Percy B. Shelley, Culler nos plantea los pronombres personales (cruciales en la forma epistolar) como «meros marcadores para denotar las diferentes modificaciones de la mente única» (merely marks employed to denote the different modification of the one mind). Parcelaciones, límites, contacto a través de las paredes categorizadoras de la identidad y de la alteridad. Esto puede observarse en «Carta a Denise» de María Victoria Atencia que analizaremos con detenimiento en el apartado correspondiente.

Como consecuencia, en parte, de este cuarto nivel, conferirá Culler al apóstrofe el rango de marcador por excelencia de atemporalidad del acto escritural: el vocativo al tú (a los pájaros, al sol, al pastor, personificados como diversos túes) subsume la esencia atemporal de la lírica, planteando una suerte de resistencia al «ser narrado», de inmediatez inmutable, en una prevalencia del discurso sobre la historia que entroniza el acto creativo sobre la anécdota (Culler 1981, 149). Esta atemporalidad preside, por ejemplo, la «Carta a un amor en Belvedere» de María Victoria Atencia a la que aludiremos más adelante. Para Culler $(1981,150)$ «los apóstrofes desplazan la estructura irreversible [de la referencialidad temporal] retirando la oposición entre presencia y ausencia del marco empírico temporal y ubicándola en el tiempo discursivo». En el marco del poema elegíaco según Culler (igualmente aplicable al ámbito de lo epistolar, añadimos nosotros) se ha producido un desplazamiento del patrón temporal por imperativo del apóstrofe que confiere carácter central a la propia evocación. Un poema que adopte formas epistolares no deja de constituir, en lo formal, una apelación a un receptor del poema en su totalidad, entendido tal poema como texto investido de destinatario. 
Así, el análisis de la poesía epistolar escrita por mujeres confirma que una buena parte de la misma se dirige a un tú o interpela al destinatario (implícito o subrayado con la presencia de vocativos). En no pocas ocasiones dentro de las obras que analizaremos, el yo poético se dirige a sí mismo en forma de tú, como apóstrofe, propuesto como segunda persona autorreflexiva por la pragmática de la lírica. Nuestra propuesta tomará, pues, las reflexiones anteriores aplicables al apóstrofe y usufructuará la concurrencia conceptual del apóstrofe, la epístola y la lírica para describir la presencia de lo epistolar en la poesía contemporánea escrita por mujeres, en función de esas cuatro capacidades operativas conferidas al apóstrofe en calidad de instrumento lírico: primero como ostensión del acto comunicativo situacional; segundo, como relación entre sujetos; tercero, como definición del yo en cuanto a la relación con el objeto (en este caso, los destinatarios de la carta); y, cuarto, como una dynamis de expansión del yo hasta la identificación (cuando no ecuación) con el tú. En el tercer nivel operativo, destaca -quizás de manera más relevante- la naturaleza del apóstrofe como receptáculo residual de una tradición lírica, en cuanto a la inmediatez perdurable del acto escritural y la declaración explícita del mismo.

\section{ERnestina de Champourcín y Rosa Chacel}

Dos escritoras de la generación del 27 publicarán varias series epistolares en la segunda mitad del siglo $\mathrm{XX}^{12}$. Nos referimos a «Cartas cerradas» y «Cartas abiertas» de Ernestina de Champourcín ${ }^{13}$, primera serie del poemario de título

${ }^{12}$ Habiendo nacido Chacel en 1898 y Champourcín en 1905 pueden ser consideradas ambas - partiendo inicialmente de un mero criterio cronológico- como «artistas pertenecientes a la Generación del 27, [puesto que] al igual que sus integrantes masculinos, nacieron en un periodo comprendido entre 1898 y 1914» (Balló 2016, 19). Para una mejor comprensión de la importancia de ambas poetas en el primer tercio del siglo XX véase la muy interesante monografía de Plaza-Agudo (2015).

13 Ernestina Champourcín -que será la única mujer junto a Josefina de la Torre incluida en la segunda edición (1934) de la antología Poesía española contemporánea de Gerardo Diego- había publicado un primer poemario, En silencio (1926), que gozó de buena acogida crítica, aunque la autora renegara más tarde de él. Le seguirán Ahora (1928), y La voz en el viento (1931), quizás su mejor obra (Díez de Revenga 2004, 192). Roberta Quance $(1988,198)$ alude a la atención crítica que recibió Champourcín por La voz en el viento y como «sólo ha vuelto a tener aceptación en los últimos años con libros como La pared transparente (1984) y Huyeron todas las islas (1988)». Por el contrario, ni siquiera se nombran los poemarios cuyas series epistolares son objeto de nuestro estudio (Cartas cerradas de 1968 y Poemas del ser y del estar de 1972), señalando Quance únicamente el marcado carácter religioso que adquiere la poesía de Champourcín a partir de la aguda crisis espiritual provocada por el exilio. Para una mejor comprensión de las circunstancias por las que atravesó Champourcín en el exilio y la solución religiosa de su crisis íntima véase Balló (2016, 242-249). 
homónimo publicado en México en 1968 y última de Poemas del ser y del estar $(1972)^{14}$. También nos referimos a la serie «Epístolas morales y religiosas» que forma parte de Versos prohibidos de Rosa Chacel ${ }^{15}$, publicado en $1978^{16}$. En ambos casos se trata de producciones que han permanecido a la sombra de obras poéticas anteriores, beneficiarias de un mayor reconocimiento crítico.

La serie «Cartas cerradas» son composiciones en verso libre con un marcado rasgo unitario que casi las convierte en secciones de un único poema. No obstante, la primera destaca por su carácter metapoemático y en ella la poeta se desmarca de los distintos realismos y de la poesía social y opta por un acercamiento al silencio: «Por eso te dedico estas cartas cerradas / que Tú has leído ya infinidad de veces» (Champourcín 2008, 149). Champourcín se dirige a Dios repitiendo ese «Tú» en mayúscula o con el vocativo «Señor», especialmente en versos iniciales: «Y te escribo, Señor, en esta madrugada, / para decirte cosas inútiles y tristes; / cosas que Tú no ignoras y que van a asfixiarme» (Champourcín 2008, 149), «Déjame que te escriba. / Quizá estas palabras aclaren el camino. / No quiero desviarme: Tú sabes que no quiero» (ibíd., 151). Aunque la modalidad epistolar es indiscutible, lo es también la diarística («Más lejos hoy que nunca en este 19 de marzo y primavera» [ibíd., 153]) y un tono confesional e intimista no exento de cierto coloquialismo. De hecho, la serie en su conjunto se aproxima al ámbito de la plegaria.

Los mismos terrenos transita la última de las series del siguiente poemario, «Cartas abiertas» en Poemas del ser y del estar. Jaime Siles ha insistido en el diálogo que crean ambas series en libros consecutivos, y cómo pueden hallarse versos en una que remiten a la obra anterior ${ }^{17}$. Se trata de un caso claro de intertextualidad.

14 Todas las obras citadas de la autora según se recogen en Poesía esencial (Chapourcín 2008).

15 Rosa Chacel había iniciado su andadura poética con la publicación en 1936 de $A$ la orilla de un pozo, un libro conformado por 30 sonetos de marcado cariz surrealista, producto en parte de su estancia en Berlín y su relación con Rafael Alberti y Maria Teresa León (Balló 2016, 220). Para Roberta Quance $(1988,199)$, Rosa Chacel opta «por una poesía neopopular de tono juguetón» en $A$ la orilla de un pozo y se decanta "por una poesía barroca, de raigambre gongorina» en Versos prohibidos -el libro que incluye la serie «Epístolas morales y religiosas» objeto de nuestro estudio- y con ello «se distingue de la mayoría de las mujeres que escribían poesía en esta época». Habrá que esperar a los poemarios de la primera etapa de Ana Rossetti (desde Los Devaneos de Erato de 1980 hasta el cambio de registro que se explicita en Punto Umbrío de 1995) para encontrar una poesía barroca de gran calado escrita por mujer.

16 Versos prohibidos de Rosa Chacel $(1992,147-163)$ fue incluido posteriormente en la recopilación Poesía (1931-1991).

17 Jaime Siles en su estudio introductorio «Ernestina de Champourcín casi desdibujada» a Poesía esencial (Champourcín 2008, XIX-LXIV) considera Poemas del ser y del estar el reverso de Cartas cerradas «y que, como una de sus partes, podría haberse titulado tal vez Cartas abiertas [...] lo que no habría dejado de ser coherente» (Champourcín 2008, LV). 
¡Otra carta, Señor!

No importa que la leas: si te la sabes ya completa,

de memoria. Pero mientras escribo

las cosas duelen menos; no hay nada más cruel

que lo que se cierra en falso (Champourcín 2008, 149).

La serie «Epístolas morales y religiosas» de Rosa Chacel está integrada por cinco composiciones de variada extensión: «Epístola moral a Sérpula», «Epístola», «Epístola a Máximo José Khan», «Epístola a Norah Borges» y «A Kazantzakis». Solo la que lleva el título de «Epístola», a secas, carece de epígrafe; mientras que a los títulos de las cuatro restantes los acompañan los epígrafes «de la verdad», «de Dios», «del arte» y «de la patria» por este orden, explicitándose de esta manera el asunto principal de cada composición y evidenciando su rotundo carácter moral, filosófico y religioso.

Rosa Chacel escribirá también una extensa «Epístola», incluida en Homenajes (Chacel 1992, 149-153) y dedicada a Julián Marías, que en absoluto esconde su pertenencia a la «más rotunda afirmación del paradigma» (López Bueno 2000, 14) horaciano; esto es, la «Epístola moral a Fabio» de Andrés Fernández de Andrada. Por el contrario, hasta cinco veces hallamos el vocativo «Fabio», empezando por el verso inicial: «Esto Fabio, que vemos, no es collado», «Por esto, ¡oh Fabio!, yo que sólo tengo», «todos, joh Fabio!, todos los mortales», «Además, Fabio, lo que bien conoces,», «Perdona ¡oh docto y sabio y caro Fabio!». El poema concreta su naturaleza epistolar e incluye alusiones al género que se elude (el elegíaco) y al género elegido (el epistolar), al que se elogia:

Tampoco quise, aunque me sea fácil,

Jugar con las palabras como pitas

Infantiles, deliciosas al tacto

De su ritmo, ofrecerte una elegía

A lo que fue el dolor de nuestra España...

[...]

Así, pues, esta epístola te envío

-género tan dilecto y genuino- (Chacel 1992, 151).

La de Chacel es sin duda la contribución más clara a esta modalidad de la epístola moral horaciana de toda la poesía española escrita por mujeres en el siglo XX. 
Ángela Figuera Aymerich, María Victoria Atencia, Gloria Fuertes y Julia Uceda

Entre las poetas de postguerra, aquellas que empiezan a publicar en los años cuarenta y cincuenta, encontramos espléndidos poemas-cartas ${ }^{18}$ de Ángela Figuera Aymerich, Gloria Fuertes, Julia Uceda y María Victoria Atencia.

«Carta abierta» de Ángela Figuera Aymerich aparece en Belleza cruel, libro publicado por primera vez en México en 1958. El poema de treinta y ocho versos incluye destinatario y dirección («Jesús de Nazaret / (Dios Hijo) / Cielo»), saludo y presentación del remitente a modo de introducción («Perdona que te escriba. De seguro / no harás cuenta de mí. Soy poca cosa. / Segundo López Sánchez, carpintero,»), una despedida cortés y paródica a un tiempo («y, en fin, no canso más, tú te harás cargo. / De obrero a obrero te lo pido y firmo: / Tu humilde servidor,») y firma («Segundo López»). En lo que sería el cuerpo de este poema-carta de marcado carácter social ${ }^{19}$, la poeta suplanta la voz de un padre de cinco hijos, de profesión carpintero, pobre, que apela a la también condición de obrero de Jesús para reclamar su ayuda en momentos difíciles.

Al mismo destinatario celestial y con la misma familiaridad dirige Gloria Fuertes su poema «Que usted bien sabe (Carta al Señor Dios. Cielo)» que aparece en Cómo atar los bigotes del tigre de 1969. Sin embargo, y a diferencia de la composición de Ángela Figuera Aymerich, lo definitorio del poema es la evidente ironía en eco que resulta de las seis repeticiones del «usted bien sabe» del título. Tal insistencia contrasta con la presupuesta omnisciencia del destinatario, a quien se envía una carta no para solicitar ayuda sino como agradecimiento por haber encontrado, se sobrentiende, pareja amorosa:



18 Adoptamos el término según lo utiliza Gloria Fuertes $(1984,30)$ en el prólogo a sus Obras incompletas.

19 Cuando se habla de poesía social o comprometida y género epistolar no puede dejar de mencionarse la obra de Gabriel Celaya Las cartas boca arriba (1951), quién, además, tuvo una profunda influencia en Ángela Figuera Aymerich. Ambos, junto con Blas de Otero, conforman la tríada fundamental de poetas vascos de posguerra. Celaya utilizará nuevamente el formato de la carta o "poema dirigido» en El corazón en su sitio, repitiendo en algunos casos destinatarios. Véase VV. AA. (1990, 115-118). 
La poesía de Gloria Fuertes ${ }^{20}$ está jalonada de poemas vinculados de variado modo a lo epistolar, o que se aproximan lúdicamente al territorio de la carta: «Carta» (Aconsejo beber hilo, 1954), «Carta de mi padre a su abuelo» (Todo asusta, 1958), «Carta a mí misma» (Poeta de guardia, 1968), «Carta a la Eme» y «Tuve carta de amor» (Historia de Gloria: amor, humor y desamor, 1980). Alguno de estos poemas evidencia el gusto de la poeta por la paronomasia y la aliteración, como «Carta a la Eme», a primera vista una lista de palabras que empiezan por la letra a la que se alude en el título. Otros, siempre desde los márgenes que permite la ironía, no evitan el ámbito de lo autobiográfico, como «Carta de mi padre a su abuelo» (Todo asusta, 1958), «Carta a mí misma» (Poeta de guardia, 1968) y «Tuve carta de amor» (Historia de Gloria: amor, humor $y$ desamor, 1980). En un tercer grupo de composiciones la poeta denuncia las injusticias sociales: en ocasiones escribiendo un mordaz acuse de recibo de las cartas que los pobres no le han escrito («Carta» de Aconsejo beber hilo, 1954), a veces apelando con evidente carga irónica a las autoridades («Señores importantes» $\mathrm{y}$ «Al señor ministro», de Mujer de verso en pecho, 1995), en algún momento creando auténticos manifiestos pacifistas («Telegrama celestial a lugares conflictivos», de Historia de Gloria: amor, humor y desamor, 1980).

El número y variedad de poemas en los que Gloria Fuertes opta por la fórmula de lo epistolar son destacables, pero quisiéramos señalar dos de aquellos que explicitan la poética de la autora, conformando así un cuarto grupo. Por un lado, «Telegramas de urgencia escribo», perteneciente a Ni tiro, ni veneno, ni navaja (Fuertes 1984, 141), espléndido metapoema a medio camino entre lo epistolar y la receta de cocina. Por otro, «Carta explicatoria de Gloria» (Sola en la sala, 1973), poema que dirige a los «Queridos lectores» y en el que la poeta recurre a la catáfora para proclamar el acto de escribir como un imperativo absoluto de su existencia, sea cual sea la circunstancia puntual que le empuje a ello:

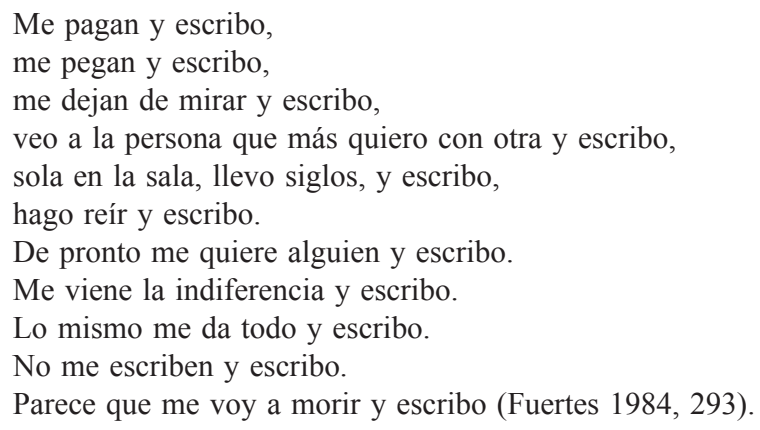

${ }^{20}$ Los títulos de Gloria Fuertes que no figuran en la «Bibliografía citada» han sido consultados a partir de su edición en Obras incompletas (1984). 
A modo de síntesis, nada más apropiado para acotar la evidente tendencia hacia lo epistolar de Gloria Fuertes - manifiesta en las composiciones ya citadas, entre otras- que las mismas palabras de la poeta en el prólogo que escribiera para sus Obras incompletas, donde conecta de manera concluyente su elección del subgénero epistolar con su toma de conciencia sobre un destinatario único, la humanidad: «Desde adolescente, casi niña, descubrí que mis poemas tenían un destinatario: la Humanidad, por eso a algunos los titulé 'poemas-cartas'» (Fuertes 1984, 30). Los ecos con la función expansiva del apóstrofe descrita por Culler («poblar el universo con fragmentos del yo») son aquí insoslayables.

«Carta» es el metapoema con el que Julia Uceda inicia el libro Zona desconocida publicado en $2006^{21}$. La composición había aparecido previamente en 2002 ocupando el lugar undécimo de las veintidós que conforman la última sección titulada «Poemas no editados en libro» ${ }^{22}$ :

La página inundada de silencio.

¿La entiende alguien?

Escribiría: Oigo

voces de muchos pájaros, o

se murió en el olvido, pero

¿lo entiende alguien?

Hábito de silencio,

de voces fragmentadas.

No, probablemente:

mejor informaciones puntuales,

que se dice.

Y la firma, sin fecha.

El resto del papel, meditando en silencio, recorrido por la pluma sin tinta, por la voz de una muda, se dejará mirar.

Quizá se entienda (Uceda 2002, 337; 2006, 15).

${ }^{21}$ Zona desconocida es el octavo poemario de la autora y recibió el Premio Nacional de la Crítica 2007. Los siete anteriores habían sido recogidos en En el viento, hacia el mar (1959-2002) publicado en 2002 (Mariposa en cenizas en 1959, Extraña juventud en 1962, Sin mucha esperanza en 1966, Poemas de Cherry Lane en 1968, Campanas en Sansueña en 1977, Viejas voces secretas de la noche en 1981 y Del Camino de Humo en 1994). Posteriormente vendrían Hablando con un haya (2010) y Escritos en la corteza de los árboles (2013).

22 Para Uceda resulta significativo el lugar que ocupan los poemas. En las «Referencias» que coloca al final de «Zona desconocida» explica: «Es ahora cuando [algunos poemas editados anteriormente sin orden previo en En el viento, hacia el mar (1959-2002)] han encontrado el lugar que les corresponde y compañía dentro de la estructura que les da sentido» (Uceda 2006, 81). 
En esta «Carta» asistimos a las vacilaciones y posteriores decisiones de quien la escribe, por lo que su tema no es otro sino el acto mismo de escribir: el orden viene dado por la toma de decisión, de ahí que la alusión a la presencia de firma y a la ausencia de fecha aparezca a mediados de poema como una asunción ( «Y la firma, sin fecha»), pero que no haya firma; de ahí que aparezca en cursiva el texto que se piensa en condicional o que acabara escribiéndose como probable, sin importar qué texto acabara siendo («Escribiría: Oigo...»); de ahí que se rectifique y se corrija («No, probablemente: / mejor informaciones puntuales»).

Ahora bien, la triple alusión al silencio - al inicio, en la mitad y hacia el final del poema- actúa como eje vertebrador de la estructura de esta carta: se apela a su dimensión espacial («La página inundada de silencio»), a su frecuencia temporal que lo convierte en rutina («Hábito de silencio») y, por último, se asume como un estado («meditando en silencio»). Por dos veces la misma pregunta retórica, con la sola variación del pronombre, reclama la comprensión de un interlocutor indefinido («i[La/lo] entiende alguien?). El último verso constituye una respuesta que ni afirma ni niega («Quizá se entienda»), sino que mantiene la duda elidiendo pronunciarse sobre la identidad del interlocutor, o destinatario. Recordemos la frecuencia con la que, según Culler (1981, 143), los poemas que incorporaban el apóstrofe como mecanismo de definición del yo en cuanto a la relación con el objeto-destinatario acababan con cuestionamientos.

Ese «alguien» sin concretar, destinatario del poema «Carta» que acabamos de analizar, aparece nuevamente hacia el final del poema «Polución» de $\mathrm{Ha}$ blando con un haya de 2010, esta vez «leyendo [una carta]»:

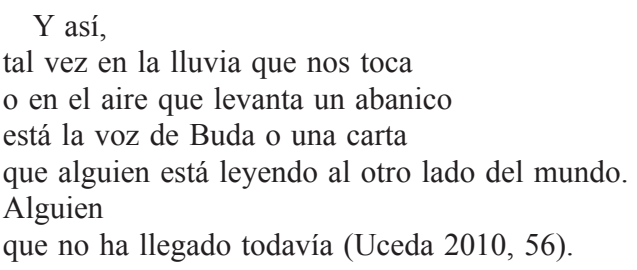

De María Victoria Atencia destacaremos dos poemas-cartas: «Carta de amor en Belvedere» y «Carta a Denise». El primero figura en El coleccionista (Atencia 1979), y se trata de una composición de cierta brevedad, en cuyos tres últimos versos se atrapa un momento presente y se trasciende, recreándose el instante exacto en que se sostiene la carta de amor entre los dedos: «El curso de las horas llega hasta los peldaños / y el mensaje postal que sostienen tus dedos / puede hacer que sosieguen corazón, pulgar e índice». Del segundo, una composición de mediana extensión ${ }^{23}$ perteneciente a La pared contigua de

${ }^{23}$ Frente a los nueve alejandrinos blancos que conforman «Carta de amor en Belvedere», «Carta a Denise» consta de catorce versos de desigual medida entre los que predominan los alejandrinos. 
1989, nos ocuparemos con mayor detenimiento, pues la riqueza con la que condensa los mecanismos comunicativos y epistolares la convierten en paradigmática:

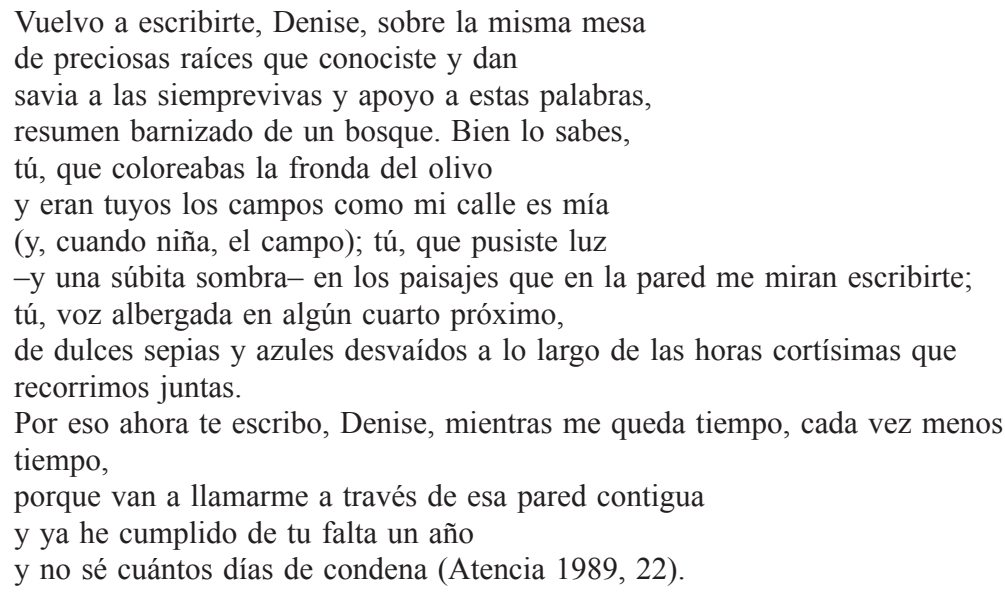

La presencia del vocativo «Denise», entre comas, en la mitad de los versos primero y undécimo vertebra el poema, en el que se distinguen los tres elementos prioritarios de la composición: la apelación al destinatario, la coordenada espacio-temporal y la alusión al mismo acto de escribir. Así, el poema que nos ocupa es un perfecto ejemplo de texto investido de destinatario, según la definición con la que nos permitimos destilar los señalamientos de Culler en relación al cuarto nivel de operatividad del apóstrofe.

La reiteración del pronombre de segunda persona es constante a lo largo del poema: ya sea átono («vuelvo a escribirte», «me miran escribirte», «te escribo»); o tónico («tú, que coloreabas la fronda del olivo», «tú, que pusiste luz», «tú, voz albergada en algún cuarto próximo»). La ubicación del tú-en-unespacio reverbera frente a un yo-en otro-espacio que refuerza, desde lo espacial, la naturaleza de «diálogo diferido» propia de lo epistolar. La epístola, acto de diálogo y de memoria a la vez, se enmarca en el poema en un entorno que es pictórico y que se refleja, a su vez, en los límites de ese entorno, que son pinturas, reflejo del «otro» ausente -la autora de los cuadros a la que se dirige la autora del poema-. Diálogo, presencia, ausencia y espacio: sutil estratagema para construirse sujeto activo «en» el espacio, a través del acto mecánico de escribir.

En este sentido, aparece la única alusión a «esa pared contigua» que da título al poemario que lo contiene, La pared contigua. Resulta evidente que «pared» puede muy bien aludir a límites espaciales, temporales, identitarios y, dado que el destinatario a quien se dirige la carta (la pintora francesa Denise Esteban) ya había fallecido, también al linde entre la vida y la muerte. Al de- 
signar su poemario con el término «pared contigua», Atencia manifiesta rotundamente su conciencia de la cercanía de los límites. No puede obviarse en este análisis la referencia al concepto de «mente única», al que recurre Culler para manifestar el alcance del apóstrofe como mecanismo de búsqueda de identidad y de la alteridad.

En el ámbito sintáctico destacan los elementos ilativos, más propios de la prosa como vehículo del pensamiento racional, que cercanos a la expresión lírica. Fijémonos en la presencia de la conjunción copulativa «y» en ocho de los catorce versos que conforman el poema -más de la mitad-, iniciando línea en cinco ocasiones. También debe subrayarse la presencia de nexos causales al inicio de verso (como «Por eso», «porque»), más propios del discurso lógico, del razonamiento filosófico (o de la simple argumentación) que del contexto lírico. La sintaxis ilativa y los nexos causales, junto con la reiterada presencia de vocativos confieren unidad y cohesión a un material poético que, primero, surge de la evocación y la apelación; segundo, se conforma a partir del molde epistolar; y, tercero, revela a un sujeto agente que es por la escritura y «en» el espacio de la escritura.

Llegados a este punto de nuestro recorrido panorámico, y a modo de conclusión preliminar, parecería posible afirmar a partir de las obras analizadas que en el género epistolar se escenifica de manera extrema el deseo de fusión de la autora (mujer poeta) con la figura del lector, el anhelo de «ser con el otro» (lector) incorporándolo al acto de definición -histórica y a la vez personal- que es en sí misma la escritura y, muy especialmente, la epístola. Si bien Gloria Fuertes aludía a toda la Humanidad (con mayúsculas) como receptora subsidiaria de su poesía aunque eligiera destinatarios puntuales para sus poemascartas (Jesús - como en el poema de Ángela Figuera Aymerich-, su abuelo, ella misma...); para Uceda y Atencia se trata de un lector copartícipe en el acto mismo del poema, un lector consustancial al texto. Por lo tanto, la elección del género epistolar no responde tan solo a la necesidad de representación del impulso de intimidad, sino a la evidencia explícita del encuentro ineludible y necesario con el otro, corporeizado en el quehacer escritural.

\section{Último Tercio DEL SIGLO XX}

No son pocas las poetas que escriben algún poema-carta en las últimas décadas del siglo XX. Sin pretender ser exhaustivos, aludiremos primero a nombres y títulos que reflejan la variedad del panorama, para acabar este apartado deteniéndonos en el análisis de «Epístola de Antinoo» de Teresa Ortiz y el poemario Cartas celtas de Eloísa Otero.

En Poesía entera (1991), una recopilación de la poesía de Angélica Becker de 1965 a 1990, hallamos tres poemas epistolares: «Carta a un solitario» (24$25)$, «Carta a un enemigo» (63-64) y «La carta» (160), en las que transita un 
planteamiento común del pretexto de la carta como imprecación que bordea el confrontamiento, entre la voz poética y un destinatario siempre ambiguo. El poema XXIV de Todo el tiempo de María Pilar López bien hubiera podido titularse «Carta a un joven poeta» en la estela de las que en prosa escribiera Rilke a principios del siglo pasado. La composición se inicia con los versos «Te prometí esta carta / ¡Qué difícil parece / escribir a un muchacho poeta y estudiante!» (López 1995, 41-43). En Los días gemelos de Ana Merino encontramos «Carta de un náufrago». En el poema, mientras el yo poético afronta las inclemencias del tiempo y no se detiene ni por la nieve, ni por el frío, ni por la niebla; en secuencia paralela «alguien» indeterminado espera junto al fuego, toma conciencia de la ausencia, sale en su búsqueda. Los dos versos finales ratifican el significado del título: «y llevará el calor de una botella / donde podré mandarte este mensaje» (Merino 1997, 34). Isabel Pérez Montalbán publicará en 1999 un poemario que lleva por título Cartas de amor de un comunista, si bien solo la última de las 37 composiciones evidencia su naturaleza epistolar con la inclusión de la palabra «carta» en el mismo título: "Carta última (Asilo)». La poeta, que en el momento de escritura de la obra era una joven de veinticinco años, asumirá como voz poética el personaje de un político comprometido y fracasado (remitente) que dirige una serie de cartas-poema a la que fuera el amor de su vida (destinatario), en el intento de que ella sea su refugio, su asilo. La casi totalidad de las composiciones que conforman el libro se inician con un encabezamiento que reitera la fórmula del sustantivo «Compañera» seguido de aposición después de coma. Todas acaban con una noticia o lista de noticias fechadas, pie de poema que actúa como vínculo entre la ficción poética y la realidad a la que tal ficción critica. El último poema del libro Calendario de Almudena Guzmán se inicia con el verso «Esperaba tu carta». En él, un yo poético instalado en la espera de una carta que no llega acaba configurando como remitente a la misma poesía: «y es la poesía quien me ha escrito» (Guzmán 1998, 72).

El poema «Epístola de Antinoo» ${ }^{24}$ de Teresa Ortiz aparece por primera vez inédito en la antología Litoral femenino de 1986. La procedencia de la $\operatorname{cita}^{25}$ que inaugura el poema se inscribe en la relectura de las figuras históricas recreadas por Marguerite Yourcenar en Memorias de Adriano. Novelista y poeta optan por la voz masculina, pero Ortiz preferirá poetizar la del joven Antinoo vez de la del emperador, en una suerte de movimiento pendular en el que,

${ }^{24}$ Se trata de una composición de cierta extensión que no reproducimos en cuerpo de texto: cincuenta y cinco versos de medida desigual.

25 «Había mucho de angustia en mi necesidad de herir aquella sombría ternura que amenazaba complicar mi vida» pertenece a la novela epistolar Memorias de Adriano de Marguerite Yourcenar. La novela es una larga carta que el emperador dirige a su sucesor, Marco Aurelio, en la que reflexiona, entre otros muchos temas, sobre el amor y la trágica muerte de Antinoo. 
según avanzan los versos, el discípulo aprenderá de su maestro invirtiendo los papeles de una forma perversa: el suicidio de Antinoo como acto de poder en el que la víctima se perpetúa en el tiempo mediante su ausencia, imponiendo a modo de venganza y desde la sombra de la culpa la imposibilidad del olvido. De este modo, «Epístola de Antinoo» pareciera inscribirse en la estela de las Heroidas: Ovidio suplanta la voz de diferentes amantes, en su mayoría personajes femeninos, que se lamentan de sus amores insatisfechos y, de manera similar, Teresa Ortiz adopta la voz de un hombre joven y vierte su heroica queja amorosa en el molde epistolar. Este se configura como el vehículo ideal para la inversión de papeles y de poderes en que el poema se regocija de manera doliente, poniendo en movimiento una exquisita confusión del yo y del tú que transciende el límite del apóstrofe como figura y con un efecto multiplicador, casi abismal, en el que la totalidad del poema-carta subsume esa función identificadora, solipsista y a la par expansiva.

Cartas celtas de Eloísa Otero apareció por primera vez en $1995^{26}$. Buena parte de las composiciones de Otero, en lugar de ubicarse en la categoría de lo metapoemático, es decir, la de los poemas que versan sobre el quehacer o proceso poético, deberían inaugurar una nueva denominación o propiciar un nuevo término que categorizara el poetizar la escritura más como ejercicio que como proceso, priorizando la dimensión física de la ejecución: ante la lucidez (y humildad) con la que se contempla la imposibilidad del decir, parece dignificarse el poema en lo que este tiene de objetivable; el material del que está hecho el lenguaje.

La poeta trabaja, ya no «en», sino «con» la superficie, desde la certidumbre de que esta es la única manera de evidenciar profundidades y honduras que, en caso de que se constituyeran en objetivo prioritario y dirigido, se perderían de manera irremediable. No se trata de un acercamiento oblicuo a lo esencial o lo trascendente. Es más sutil. Si hubiera una fórmula de apropiarse, acotar o maniobrar con lo trascendente o lo esencial (aquello que no puede decirse, con palabras), se encontraría en el respetuoso hueco dejado (entre las palabras). Este hueco debe ser entendido y manejado no solo como espacio, sino también como objeto. Ahí es cuando entra, más que el ejemplo de un verso concreto, la elección previa, la opción por el molde genérico: la carta.

Lo anterior se manifiesta en los siguientes versos que inician poema: «Con el tiempo parece ir asentándose la rancia teoría de que / la permanencia es la forma / condición inexcusable de ese silencio de cuerda tendida» (Otero 2008, 29). Conformado el hueco o silencio o vacío, este debe compartirse.

La separación epistolar no se da solo entre el remitente y el destinatario, sino entre la poeta y su propio poema. Así, como si de un ajuste de cuentas

\footnotetext{
${ }^{26}$ Algunos de los poemas de Cartas celtas (1995) aparecieron en la antología Ellas tienen la palabra (Benegas y Munárriz 1997, 489-499). La obra de Eloísa Otero fue reeditada en 2008 con la inclusión de un apartado que lleva por título «Otros poemas».
} 
con los conocidos versos de Pessoa se tratara ${ }^{27}$, el último poema de Cartas celtas insiste en que la vivencia es una y el texto es otro; que hay un lapso de tiempo que separa la experiencia de su posterior plasmación, un sentido de lo efímero en todo recuento, porque el acto histórico y su documentación siempre quedan separados por el acto temporal de su escritura:

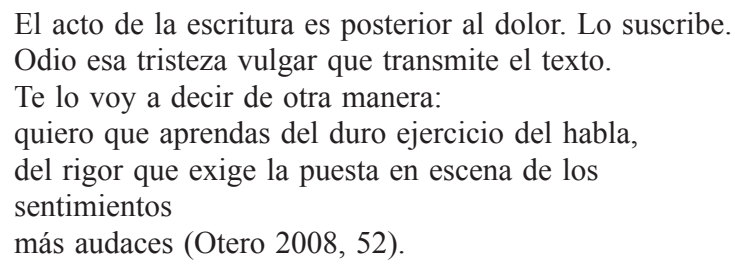

Nada de esto va en menoscabo de los postulados que defienden el valor supremo del arte como recreación de la realidad, una realidad superior a la misma realidad; se trata de insistir en esa «pared contigua» de la que se valía María Victoria Atencia. Ninguna de las autoras necesita fusionar dos espacios que, de manera incuestionable, perciben distintos. El dolor (verdadero o fingido), la pena, los placeres, los gozos o la indiferencia de la vida son de la vida y el texto no necesita conformarse con sucesos de segunda mano, con sucedáneos, con despojos. A partir de la constatación de que el texto se configura con, por y desde las palabras (y el «dolor» y la «tristeza» a la que apela Otero en sus poemas lo son -palabras-), el procedimiento dignifica el resultado. El texto es un artefacto, un constructo: la suya es la naturaleza del artificio.

Así, a modo de manual para escolares de cursos básicos, en los poemas de Cartas celtas de Eloísa Otero se suceden las instrucciones sobre cómo el destinatario debe leer: por ejemplo, «Donde se dice 'la necesidad de renunciar a las ilusiones' / debe leerse: / la necesidad de renunciar a las ilusiones» (Otero 2008, 13). Igualmente abundan las advertencias de cómo no debe entender esa lectura. Por ejemplo: «No te lo imagines como una carta triste. / Nunca pienses que entre no estar / contigo / y la tristeza / hay una relación lógica, firme» (ibíd., 15). No son, pues, metapoemas, sino quizás «parametapoemas», que ubican su vocación metapoemática no en el poema como objeto, sino en la objetualización de la recepción. Una vez más, lo dialógico de lo epistolar surge, esta vez en la reflexión consciente sobre los extremos que definen su esencia: el proceso creativo y el proceso de la recepción.

La reflexión aparentemente trivial sobre los detalles más prosaicos de la forma, que es la materia misma de la literatura, alcanza -con evidente ironíael ámbito de la autocorrección más insignificante y de menor trascendencia:

27 «El poeta es un fingidor. / Finge tan completamente/ que hasta finge que es dolor/ el dolor que en verdad siente» es la primera estrofa del poema «Autopsicografía» de Fernando Pessoa $(2001,545)$ en la traducción de Ángel Campos Pámpano. 
Debería al fin cuidar la letra

- dicen que las formas deberían ser cuidadas:

pero no tengo ningún problema en mecanografiar la carta (Otero 2008, 14).

Debería contarte (paso a mayúsculas)

DEBERÍA CONTARTE CÓMO LE BUSCO, no,

CÓMO LE BUSCO no, cómo le ESPERO,

cómo le he confundido, cómo zozobro (demasiadas zetas) (Otero 2008, 21).

Pareciera rendir homenaje al genial uso que de la figura correctionis hiciera Garcilaso de la Vega en su Elegía II «A Boscán»»; al fin, un ensayo epistolar en el que el autor tantea los espacios de lo elegíaco, lo satírico y lo epistolar.

La supremacía de la forma como esencia de la auténtica veracidad del poema se proclama en la composición que nos parece más reveladora de Cartas celtas:

Te rescribo: «la historia de la carta anterior tiene algún viso de verdad tan sólo, la certidumbre de que pueda ser así, o que se entienda así con ser de otra manera».

Aquí nada resulta imperceptible: la palabra es una estrategia.

No hay diferencia entre aquello de lo que un libro habla

y la manera como está hecho.

y éste es en parte mi relato de tu historia y de su voz, pero también un embalaje (Otero 2008, 33).

Estrategia, embalaje. Si un libro habla de «la manera cómo está hecho», este libro, Cartas celtas de Otero, habla de la elección del molde epistolar porque, como queda apuntado en una cita que inaugura uno de los poemas, «La única manera de estar cerca de aquello que está lejos es seguir estando lejos» (Otero 2008, 34); acertada interpretación de lo epistolar como la única forma de sostener, de no romper un contacto, no ya que se mantiene a pesar de la distancia, sino precisamente por y gracias a la distancia. Y aquí es necesario interpretar «distancia» también como artificio.

En esa línea, la ausencia del destinatario en «Carta a Denise», que no se encuentra presente en el momento de la escritura, posibilita su invocación y ahonda en el «quehacer escritural» como lugar de encuentro o como «intensa implicación con la situación» (Culler 1981, 138). Tampoco estará el remitente

${ }^{28}$ Los versos de Garcilaso de la Vega a los que nos referimos son: «Yo enderezo, señor, en fin mi paso / por donde vos sabéis que su proceso / siempre ha llevado y lleva Garcilaso». La crítica se ha ocupado en diversas ocasiones del asunto desde el clásico estudio «Sátira y poética en Garcilaso» de Claudio Guillén (1988). 
de «Epístola de Antinoo» en el momento de la lectura, habiendo ya entregado su vida el autor en el momento de lectura de su carta-testamento por parte del destinatario. Lo que ofrecen en común los ejemplos seleccionados $-y$ según se ha visto en los análisis previos- es la presencia continuada y constante del vínculo entre ambas entidades (yo, sujeto lírico; tú, destinatario de la cartapoema). Ése pudiera ser el sentido de la «pared contigua» del poema de María Victoria Atencia. Ése parece ser el referente último de lo que Eloísa Otero refiere con la acertada imagen «cuerda tendida» a la que antes nos hemos acercado:

Con el tiempo parece ir asentándose la rancia teoría de que la permanencia es la forma, condición inexcusable de ese silencio de cuerda tendida que a veces se da (Otero 2008, 29).

Con la elección del género epistolar para su libro, Otero muestra su necesidad vital ${ }^{29}$ de mantener la ilusión de continuidad del vínculo. Recordemos la cita que inicia el poema «El estilo epistolar celado» a la que nos habíamos referido con anterioridad. Dice así: «La única manera de estar cerca de aquello que está lejos es seguir estando lejos» $(2008,34)$. Lo que no deja de ser una manera de aludir a la causa o motivo último de lo epistolar y a la paradoja intrínseca (como gesto autoconsciente) que se le confiere al apóstrofe. Por otro lado, y en muchos casos, como en "Carta explicatoria de Gloria» de Gloria Fuertes, «Carta» de Julia Uceda o el poemario Cartas celtas de Eloísa Otero, la opción de género rebasa el ámbito de lo puramente formal para constituirse, también, en materia, contenido poético, de manera ostensiva, tanto en lo comunicativo («declaro que quiero comunicar») como en lo metapoético («mi poesía declara que esto es poesía»).

A todo este consciente navegar en la ¿superficie? del lenguaje no le puede ser ajeno el corrosivo de la ironía: como herramienta para evidenciar la profundidad insondable de lo aparente; como cuestionamiento de la funcionalidad del lenguaje en tanto que reflejo de la circunstancia vital; como asidero para la rebelión y la cordura. De hecho, el componente irónico de lo epistolar femenino reposa sobre una larga tradición a la que apunta Carmen Martín Gaite en Desde la ventana ${ }^{30}$ : «No en vano se ha elegido el género epistolar, tan propicio al desahogo y la ironía, para colorear con ejemplos concretos una queja que pierde así toda la altisonancia teórica de los discursos varoniles. Y, como con-

\footnotetext{
29 Maria Zambrano señala en las páginas casi iniciales de su estudio La confesión: género literario que «[1] que diferencia a los géneros literarios unos de otros, es la necesidad de la vida que les ha dado origen. No se escribe ciertamente por necesidades literarias, sino por necesidad que tiene la vida de expresarse» (Zambrano [1943] 1988, 13).

${ }^{30}$ El señalamiento de Martín Gaite se refiere a una carta en prosa de 1866 escrita por Rosalía de Castro: «Carta a Eduarda».
} 
secuencia, su eficacia es mucho mayor» (Martín Gaite 1987, 81). Para Martín Gaite la selección del subgénero epistolar posibilita un doble espacio de desahogo e ironía.

\section{EN EL SIGLO XXI}

Al inicio del nuevo siglo Lucía Etxebarría se dirige una carta a sí misma en segunda persona: "Carta a ti misma» de Estación de infierno (Etexebarría 2001, 93-94). En el cruce entre lo laudatorio y lo elegíaco encontramos una «Nota a Emily Dickinson» en el poemario Camaradas de Ícaro de Aurora Luque. Al igual que el resto de composiciones que conforman el último apartado del libro, «La hierba del Elíseo», en esta Luque también rinde homenaje a una poeta admirada. Sin ser propiamente una epístola, el primer verso se inicia con una interpelación a un tú que alude a la poeta americana que aparece en el título, la destinataria: «Tú también habitaste en el Planeta». Si este verso inicial subraya la inclusión de Emily Dickinson en el grupo de seres a los que también pertenece la autora de la voz poética, los versos finales acentuarán metapoemáticamente la distancia: «a los demás nos queda, únicamente/ una nostalgia huérfana/ del discurso de Orfeo» (Luque 2003, 60).

La última generación de poetas ${ }^{31}$ también acude a lo epistolar para volcar su contenido poético, aunque de modo ciertamente singular. Así, por ejemplo, incluida en la antología La manera de recogerse el pelo. Generación Blogger de David González encontramos una extensa composición que supera los ochenta versos de Déborah Vukusic (González 2010, 106-109), a medio camino entre lo testimonial y el monólogo dramático ${ }^{32}$. Por lo que atañe al monó-

${ }^{31}$ Sobre la última generación de poetas escribe M. ${ }^{a}$ Cinta Montagut: «A partir de 2005 se produce en la poesía española un fenómeno, paralelo a la poesía en otras lenguas, que es el de la irrupción de la escritura poética a través de la red, del ciberespacio, de Internet. Los poetas y las poetas dan a conocer sus versos a través de sus propios blogs personales con lo que la transmisión de la poesía y la relación con quienes la leen se hace inmediata, viva, el poema se convierte en post y viaja por la red a todas partes, ya no hay barreras ni imposibles. El poema se comparte y se comenta casi al mismo tiempo que se escribe y eso es un hecho completamente nuevo y hasta cierto punto revolucionario. Y lo más característico de este fenómeno es la abundancia de mujeres poetas...» $(2014,218)$. Por otro lado, resulta relevante la existencia de estudios sobre el intercambio epistolar vía e-mail que llevan a cabo las poetas actuales, utilizando así las TIC y relegando el correo postal a un segundo término. Véase, por ejemplo, Logroño Carrascosa (2018, 557-579).

32 Desde la perspectiva de la teoría genérica y según García Berrio y Huerta Calvo la «única solución solvente» para la clasificación de géneros producto de la hibridación es la que, siguiendo los estudios entre otros de Eduard von Hartmann y Albert Guérard distingue tres grados distintos dentro de cada género $(1992,148)$. 
logo, sería la resultante del género dramático en su grado dramático-lírico o, como evidencia la composición de Vukusic, del género lírico en su grado lírico-dramático. Paradójica pirueta en la catalogación genérica para aludir a la hibridación de la hibridación. Por otro lado, el monólogo dramático y la modalidad epistolar comparten como rasgo dominante la elocución apelativa que dirige explícitamente un yo a un tú (poético o dramático). Así, pues, su pertenencia al género epistolar se evidencia desde la alusión del verso inicial «hace unos días quería enviar una carta». El poema describe el proceso, no de escritura, sino de envío: un homenaje no exento de la ironía que se produce al contemplar un acto anacrónico, de otros tiempos, obsoleto y provisto de cierto grado de romanticismo.

\section{Conclusiones}

El presente recorrido nos ha llevado a singularizar una red conformada por poemas que evidencian su pertenencia al género de lo epistolar en el siglo pasado y principio del actual. Un corpus de poemas que transparenta cierto homenaje a una tradición que alcanzara su cima en los siglos XVI y XVII, y que ha llegado, no obstante sus altibajos, incluso a las poetas más recientes en las primeras décadas del presente siglo. Respondería esto a la tesis de que todo poema individual es parte del «Poema único» ${ }^{33}$ y que remite al resto de poemas.

La elección del molde epistolar, al no estar simultáneamente presentes ni el yo poético y ni el destinatario, posibilita la ilusión de continuidad del vínculo, sosteniendo no ya en la figura o en el verso, sino en la ontología misma de la composición (la carta-poema) una duplicidad en la definición del yo poético desde el tú receptor. La carta nace de esa imposibilidad: la de la presencia simultánea de destinatario y remitente. La carta deviene, pues, la esencia misma del acto de la escritura: siempre se escribe para alguien que no está y la epístola subsume, en forma de género, lo que el apóstrofe opera como figura. Carta y escritura son el soporte material de la comunicación en la ausencia, así como de la distancia, de manera similar a cómo el apóstrofe retira «la oposición entre presencia y ausencia del marco empírico temporal y ubicándolo en el tiempo discursivo» (Culler 1981, 149).

Pero la opción de género rebasa el ámbito de lo puramente formal para constituirse también en materia, en contenido poético de manera ostensiva, tanto en lo comunicativo («declaro que quiero comunicar») como en lo metapoético («mi poesía declara que esto es poesía»). En las composiciones en las que se logra materializar el vínculo entre los dos participantes del proceso de

33 Para Heidegger $(1987,35)$ «ningún poema individual, ni siquiera su conjunto lo dice todo. Sin embargo, cada poema habla desde la totalidad del Poema único y lo dice cada vez». 
comunicación epistolar, se poetiza sobre ese mismo vínculo: continuidad -o contigüidad - en lugar de simultaneidad, de una manera que vuelve a evocar esa inmediatez atemporal del apóstrofe.

Los rasgos epistolares enlazan con la poesía que levanta el vuelo desde el ancla de lo anecdótico: se trata de una poesía plenamente consciente de su naturaleza comunicacional, pero con una acentuada impronta irónica que a veces arranca del descrédito sobre el medio que toda conciencia entraña. Lo primero entronca con el primer nivel de análisis del apóstrofe según Culler $(1981,137)$, lo segundo enlaza con el señalamiento del apóstrofe por parte del mismo crítico como gesto concurrente de lo ridículo y lo sublime (ibíd., 144).

Lo epistolar en el discurso poético femenino sirve también como cauce para una poesía de amplio calado metapoemático y lo que pudiera hacer de lo epistolar un cauce tan atrayente es la exhibición de su elección: metaliteraria -en segundo grado- y comunicativa -en primer grado-. De la variedad que señalara Sánchez Robayna $(2000,141)$ como inherente al género participan las composiciones de molde epistolar que hemos analizado: bien sea como realización de la epístola moral -marcadas por el componente filosófico o religioso-, bien acercándose en diferente grado a lo personal o familiar -que en ocasiones no esconde cierta vertiente prosaica-, bien como cauce de ideas poéticas. Quizá sea dicho cauce el que mejor transpira las esencias de la realización lírica definidas en el molde epistolar como acto ostensivo de instanciación poética, pero también como acto autoconsciente de constituir un receptáculo atemporal de una doble tradición, tanto lírica como epistolar.

Si hubiera que establecer conclusiones cuantitativas $-\mathrm{y}$ al contrario de lo que pudiera presuponerse, dado lo «adjetivable» de femenino del género epistolar- no es ingente el número de composiciones poéticas que explicitan su adscripción al formato de la carta en la poesía peninsular escrita por mujeres a lo largo del siglo pasado y de las primeras décadas del presente. Sin embargo, aun no identificando de manera incuestionable una tendencia o una corriente frecuentemente transitada, el hilo no se ha roto y las hebras permiten al lector, al crítico, reconstruir lo que permanece de un género: a modo de legado.

\section{BIBLIOGRAFÍA CITADA}

Atencia, Maria Victoria. 1979. El coleccionista. Sevilla: Calle del Aire.

Atencia, Maria Victoria. 1989. La pared contigua. Madrid: Hiperión.

Azaustre, Antonio y Juan Casas. 1997. Manual de retórica española. Barcelona: Ariel.

Balló, Tània. 2016. Las sinsombrero. Sin ellas la historia no está completa. Barcelona: Espasa.

Becker, Angélica. 1991. Poesía entera. Madrid: Visor.

Benegas, Noni y Jesús Munárriz, ed. 1997. Ellas tienen la palabra. Dos décadas de poesía española. Antología. Madrid: Hiperión.

Chacel, Rosa. 1992. Poesía (1931-1991). Barcelona: Tusquets. 
Champourcín, Ernestina de. 2008. Poesía esencial. Madrid: Fundación Banco Santander.

Culler, Jonathan. 1981. The Pursuit of signs. Semiotics, Literature, Deconstruction. Ithaca, Nueva York: Cornell University Press.

Díez de Revenga, Francisco Javier. 2004. Las Vanguardias y la generación del 27. Madrid: Síntesis.

Encinar, Ángeles. 2000. «La narrativa epistolar en las escritoras españolas actuales». En Mujeres novelistas en el panorama literario del siglo XX, ed. Marina Villalba, 33-50. Cuenca: Universidad de Castilla-La Mancha.

Etxebarría, Lucía. 2001. Estación de infierno. Barcelona: Lumen.

Fernández de Andrada, Andrés. 1993. Epístola moral a Fabio y otros escritos. Ed. Dámaso Alonso; estudio preliminar de Juan F. Alcina y Francisco Rico. Barcelona: Crítica.

Figuera Aymerich, Ángela. 1958. Belleza cruel. Ciudad de México: General de Ediciones.

Fuentes Gutiérrez, Dolores. 2000. «Las mujeres y las cartas: otra manera de novelar el yo. Gertrudis Gómez de Avellaneda y Carmen Riera». En Mujeres novelistas en el panorama literario del siglo XX, ed. Marina Villalba, 339-352. Cuenca: Universidad de Castilla-La Mancha.

Fuertes, Gloria. 1984. Obras incompletas. Madrid: Cátedra.

Fuertes, Gloria. 1980. Historia de Gloria. Madrid: Cátedra.

Fuertes, Gloria. 1995. Mujer de verso en pecho. Madrid: Cátedra.

García Berrio, Antonio y Javier Huerta Calvo. 1992. La Poética. Tradición y modernidad. Madrid: Cátedra.

Garrido Gallardo, Miguel Ángel. 2009. El lenguaje literario. Vocabulario crítico. Madrid: Síntesis.

González, David, ed. 2010. La manera de recogerse el pelo. Generación Blogger. Madrid: Bartleby Editores.

Guillén, Claudio. 1985. Entre lo uno y lo diverso. Introducción a la literatura comparada. Madrid: Crítica.

Guillén, Claudio. 1988. El primer Siglo de Oro. Estudios sobre géneros y modelos. Barcelona: Crítica.

Guzmán, Almudena. 1998. Calendario. Madrid: Hiperión.

Heidegger, Martin. 1987. De camino al habla. Barcelona: Ediciones del Serbal.

Jiménez Millán, Antonio. 2009. «La carta y la caligrafía». Litoral. Revista de Poesía, Arte y Pensamiento 248: 10-27.

Logroño Carrascosa, Isabel. 2018. «Consideraciones sobre la identidad autorial de las poetas navarras actuales en el correo electrónico». En Identidad autorial femenina y comunicación epistolar, ed. María Dolores Martos Pérez y Julio Neira Jiménez, 557-579. Madrid: UNED.

López, María Pilar. 1995. Todo el tiempo. Barcelona: Los Libros de la Frontera.

López Bueno, Begoña. 2000. «El canon epistolar y su variabilidad». En La epístola, ed. Begoña López Bueno, 11-26. Sevilla: Universidad de Sevilla.

Luján Atienza, Ángel Luis. 2005. Pragmática del discurso lírico. Madrid: Arco-Libros.

Luque, Aurora. 2003. Camaradas de Ícaro. Madrid: Visor.

Martín Gaite, Carmen. 1973. La búsqueda de interlocutor y otras búsquedas. Barcelona: Nostromo.

Martín Gaite, Carmen. 1987. Desde la ventana. Madrid: Espasa-Calpe.

Merino, Ana. 1997. Los días gemelos. Madrid: Visor.

Montagut, M. ${ }^{a}$ Cinta. 2014. Tomar la palabra. Aproximación a la poesía escrita por mujeres. Barcelona: Aresta Mujeres. 
Navarro Gala, María Josefa. 2011. «Los modelos discursivos femeninos en la preceptiva epistolar: la 'Cosa nueva' de Gaspar de Texeda». Estudios Humanísticos. Filología 33: 219-243.

Ortiz, Teresa. 1986. «Epístola de Antinoo». En Litoral femenino. Literatura escrita por mujeres en la España Contemporánea, ed. Lorenzo Saval y Jesús García Gallego. Málaga: Revista Litoral.

Otero, Eloísa. 2008. Cartas celtas y otros poemas. León: Ediciones Leteo.

Otxoa, Julia. 1985. Cuaderno de bitácora. Pasajes: Ayuntamiento de Pasajes.

Pérez Montalbán, Isabel. 1999. Cartas de amor de un comunista. Valencia: Germanía.

Pessoa, Fernando. 2001. Un corazón de nadie. Antología poética (1913-1935). Traducción Ángel Campos Pámpano. Barcelona: Círculo de Lectores.

Plaza-Agudo, Inmaculada. 2015. Modelos de identidad en la encrucijada: imágenes femeninas en la poesía de las escritoras españolas (1900-1936). Málaga: Universidad de Málaga.

Quance, Roberta. 1988. «Hago versos, señores...». En Breve historia feminista de la literatura española (en lengua castellana), coord. Iris M. Zavala, 185-210. Barcelona: Anthropos.

Riera, Carme. 1982. «Literatura femenina, ¿un lenguaje prestado?». Quimera 18: 9-12.

Riera, Carme. 1989. «Grandeza y miseria de la epístola». En El oficio de narrar, ed. Marina Mayoral, 147-158. Madrid: Cátedra.

Rosetti, Ana. 1980. Los devaneos de Erato. Valencia: Prometeo.

Sánchez Espinosa, Gabriel. 2001. «Madame de Sévigné y la carta familiar en España durante el siglo XVIII». En Recepción de autores franceses de la época clásica en los siglos XVIII y XIX en España y en el extranjero, ed. Mercedes Boixareu y Roland Desné, 111-123. Madrid: UNED.

Sánchez Robayna, Andrés. 2000. «La epístola moral en el Siglo de Oro». En La epístola, ed. Begoña López Bueno, 129149. Sevilla: Universidad de Sevilla

Silvestre, Horacio, ed. 1996. Quinto Horacio Flaco. Sátiras, Epístolas, Arte Poética. Trad. Horacio Silvestre Landrobe. Madrid: Cátedra.

Uceda, Julia. 2002. En el viento, hacia el mar (1959-2002). Sevilla: Fundación José Manuel Lara.

Uceda, Julia. 2006. Zona desconocida. Sevilla: Fundación José Manuel Lara.

Uceda, Julia. 2010. Hablando con un haya. Valencia: Pre-textos.

Uceda, Julia. 2013. Escritos en la corteza de los árboles. Valencia: Pre-textos.

Zambrano, María. (1943) 1988. La confesión: género literario. Madrid: Mondadori.

VV. AA. 1990. Gabriel Celaya: premio nacional de las letras españolas, 1986. Barcelona: Anthropos.

VV. AA. 2009. «Poemas a la carta». Revista Litoral 248: 320-351.

Fecha de recepción: 26 de septiembre de 2018 .

Fecha de aceptación: 28 de enero de 2019. 